\title{
EFFECTS OF SURFACE AND SUBSURFACE DRIP IRRIGATION ON PHYSIOLOGY AND YIELD OF ‘GODELLO’ GRAPEVINES GROWN IN GALICIA, NW SPAIN
}

\author{
EFEITOS DA REGA SUPERFICIAL E SUBSUPERFICIAL SOBRE A FISIOLOGIA E PRODUÇÃO DA \\ VARIEDADE ‘GODELLO’ NA GALIZA, NOROESTE DE ESPANHA
}

\author{
José M. Mirás-Avalos ${ }^{1}$, María Fandiño ${ }^{2}$, Emiliano Trigo-Córdoba ${ }^{1,2}$, Emma M. Martínez ${ }^{2}$, José Moutinho- \\ Pereira $^{3}$, Carlos M. Correia ${ }^{3}$, Lia T. Dinis ${ }^{3}$, Benjamín J. Rey ${ }^{2}$, Aureliano C. Malheiro ${ }^{3}$, Javier J. Cancela ${ }^{2}$ \\ ${ }^{1}$ Estación de Viticultura e Enoloxía de Galicia (EVEGA-INGACAL), Ponte San Clodio s/n. 32428, Leiro, Ourense, Spain. \\ ${ }^{2}$ GI-1716. Dpto. Ingeniería Agroforestal, Universidade de Santiago de Compostela, Escola Politécnica Superior, Campus Univ. s/n, 27002, Lugo, \\ Spain. \\ ${ }^{3}$ CITAB - Centre for the Research and Technology of Agro-Environmental and Biological Sciences, University of Trás-os-Montes e Alto Douro, \\ 5000-801, Vila Real, Portugal. \\ *corresponding author: e-mail: javierjose.cancela@usc.es
}

(Received 14.01.2017. Accepted 22.06.2017)

\section{SUMMARY}

Irrigation has been considered a controversial practice in European traditional viticulture due to potential alterations in the balance between vegetative growth and yield. In this regard, the influence of surface (DI) and subsurface (SDI) drip irrigation on physiological performance of the 'Godello' grapevine (Vitis vinifera L.) cultivar was compared with a non-irrigated control (R) over three consecutive growing seasons (20122014) in NW Spain. Irrigation improved vine water status; R plants reached a minimum of midday leaf water potential of $-1.5 \mathrm{MPa}$, whereas DI and SDI plants reached $-1.3 \mathrm{MPa}$. Stomatal conductance was unaffected by irrigation as well as chlorophyll $a$ fluorescence. However, photosynthetic pigments were present at higher concentrations in leaves from irrigated plants than in those from $\mathrm{R}$ plants in 2013 . In addition, $\mathrm{R}$ plants showed higher values for the indicators of oxidative damage. No significant yield improvements were observed for irrigated plants, although the trend was to obtain slightly higher yields under irrigation in years with low rainfall amounts. This may not encourage growers to establish irrigation systems on their vineyards. However, these results may be important with the objectives of stabilizing yield from year to year.

\section{RESUMO}

A rega tem sido considerada uma prática controversa na viticultura tradicional Europeia devido a potenciais alterações no equilíbrio entre crescimento vegetativo e rendimento. A este respeito, a influência da irrigação por gotejamento superficial (DI) e subsuperficial (SDI) sobre o desempenho fisiológico da variedade ‘Godello' (Vitis vinifera L.) foi comparada com uma testemunha em condições de sequeiro (R) ao longo de três anos consecutivos (2012-2014) no noroeste de Espanha. A rega melhorou o estado hídrico da videira; as plantas do tratamento R atingiram potenciais hídricos foliares ao meio-dia de $-1.5 \mathrm{MPa}$, comparativamente a um valor de $-1.3 \mathrm{MPa}$ para as plantas dos tratamentos DI e SDI. A conductância estomática e a fluorescência da clorofila $a$ não foram afectadas pela rega. No entanto, os pigmentos fotossintéticos apresentaram maiores concentrações em folhas de plantas regadas quando se comparam com as plantas do tratamento R em 2013. Além disso, as plantas do tratamento R apresentaram valores superiores para os indicadores de danos oxidativos. Não foi detectado nenhum incremento do rendimento nas plantas regadas, embora se tenha observado uma tendência para obtenção de rendimentos ligeiramente mais elevados sob rega em anos com baixa pluviosidade. Tal poderá não encorajar aos viticultores a implementar sistemas de rega nas suas vinhas. No entanto, estes resultados podem ser importantes para a estabilização do rendimento de ano para ano.

Key words: chlorophyll fluorescence, leaf metabolites, stomatal conductance, Vitis vinifera, yield.

Palavras-chave: fluorescência da clorofila, metabolitos foliares, condutância estomática, Vitis vinifera, rendimento.

\section{INTRODUCTION}

Irrigation is currently used as a cultural practice to improve and standardize grapevine (Vitis vinifera L.) yield and quality (Battilani and Mannini, 2000). Deficit irrigation systems have been tested worldwide in order to assess the effects on vine vegetative growth, yield and must quality (e.g. dos Santos et al., 2003; Intrigliolo and Castel, 2010), even under humid climates (Reynolds et al., 2007). The main finding of these studies is that irrigation protocols must be

\section{2}

This is an Open Access article distributed under the terms of the Creative Commons Attribution License (http://creativecommons.org/licenses/by/4.0), which permits unrestricted use, distribution, and reproduction in any medium, provided the original work is properly cited. 
adapted to the conditions of the region (climate, soil) and the cultivar considered.

Irrigation exerts an effect on vine growth and yield caused by changes in vine physiology. Stomatal closure seems to be the main cause for the decrease in the photosynthetic rate under mild drought conditions (Chaves et al., 2002). However, non-stomatal effects can occur, such as decreasing in the photosystem II efficiency, which has been reported under fieldgrown conditions (Escalona et al., 1999; Maroco et al., 2002). Hence, it seems adequate to study vine physiology under irrigation conditions for different cultivars located in different regions.

Reports on climate change predict variations in rainfall distribution and increases in air temperature (Cruz et al., 2009). Concerned about this, vinegrowers in Galicia (NW Spain) are increasingly using irrigation in their vineyards. However, little information is available on the effects that irrigation may exert on Galician grapevine cultivars (Fandiño et al., 2012; Trigo-Córdoba et al., 2015; Martínez et al., 2016; Cancela et al., 2017).

'Godello' is one of the finest white grapevine varieties grown in Spain, with crucial importance for the quality and typicity of Galician wines, especially those from the Designations of Origin (DO) Ribeiro, Monterrei and Valdeorras. However, the physiological response of this cultivar to irrigation has not been previously evaluated in the region (Cancela et al., 2015). Therefore, the aim of this study was to examine the effects of two types of drip irrigation on the physiology, biochemistry and yield of 'Godello' grapevines, comparing them with a nonirrigated control. For this purpose, measurements of leaf water potential, stomatal conductance, chlorophyll $a$ fluorescence, minerals, metabolites, oxidative stress indicators and yield were conducted.

\section{MATERIAL AND METHODS}

\section{Field conditions and plant material}

This study was conducted during three consecutive seasons (2012-2014) in a commercial 'Godello' vineyard (Vitis vinifera L.) grafted in 1997 onto 110Richter rootstock at a spacing of 1.35 by $1.95 \mathrm{~m}$ (3,800 vines/ha). This vineyard was located in A Rúa (Ourense, NW Spain) within the Valdeorras DO $\left(42^{\circ}\right.$ 23 ' $59^{\prime}$ ' N, $7^{\circ} 7$ ' $15^{\prime}$ ' W, elevation $320 \mathrm{~m}$, mean slope was $18 \%)$. Vines were trained to a vertical trellis on a double cordon system oriented in the North-South direction. Standard cultural practices in the region were applied to all treatments.
The soil presented a loamy texture (46.2\% sand, $31 \%$ silt and $22.8 \%$ clay), a low $\mathrm{pH}\left(\mathrm{pH}\left(\mathrm{H}_{2} \mathrm{O}\right) 4.99\right)$ and a medium organic matter content $(2.26 \%)$. Soil depth was, approximately, $1.2 \mathrm{~m}$ and total available water was about $170 \mathrm{~mm} / \mathrm{m}$.

The climate of this region has been classified as cool, humid with cool nights (Fraga et al., 2014), presenting characteristics both from Atlantic and Mediterranean. Climate data were collected from a weather station located, approximately, $7 \mathrm{~km}$ away from the vineyard. The reference evapotranspiration $\left(E_{0}\right)$ was computed with the Penman-Monteith equation using the methodology proposed by Allen et al. (1998) for limited weather data, i.e., estimating the actual vapor pressure from the daily minimum temperature and solar radiation from daily maximum and minimum temperature.

\section{Irrigation and experimental design}

Three treatments were established following a completely randomized block design with four replications (seven plants each). The treatments were: rain-fed (R), surface (DI) and subsurface (SDI) drip irrigation. The surface irrigation pipes were in the vineyard row at $40 \mathrm{~cm}$ above the soil, whereas the subsurface pipes were $40 \mathrm{~cm}$ deep into the soil. Both systems were equipped with $2 \mathrm{~L} / \mathrm{h}$ emitters (Cancela et al., 2016), one emitter per vine in the case of DI, whereas SDI had one emitter per meter. The irrigation treatment began at flowering, early June, and finished at ripeness (mid to late August), approximately two weeks prior to harvest. During this period, water was daily applied early in the morning, from Monday to Sunday, with an average total dose per season of 80 , 63 and 46 mm, in 2012, 2013 and 2014, respectively.

The irrigation treatment began the first of June and finished in the middle of August in 2012; during 2013, irrigation started on July and finished at the end of August; however, in 2014, due to problems with the pumping system, irrigation started in the middle of July and finished at the end of August. During these seasons, water was applied for 59, 46 and 34 days in 2012, 2013 and 2014, respectively, at a rate of $1.5 \mathrm{~h}$ per day, in order to reduce the evaporation losses. Average irrigation depths were $1.14 \mathrm{~mm}$ and $1.54 \mathrm{~mm}$, for DI and SDI, respectively.

\section{Leaf water potential and stomatal conductance}

Midday leaf water potential was assessed fortnightly on one mature and healthy leaf of three plants per replicate (thus, twelve plants per treatment), using two pressure chambers (PMS Model 600, Albany, OR, USA and SoilMoisture Inc., Santa Barbara, CA, USA), which have shown good correlation with other equipments, as water activity meters (Martínez et al., 
2013). These measurements were carried out on healthy fully-expanded leaves from the middle third of the shoots, all at similar growth stages and with no alterations, and fully-exposed to direct solar radiation (Maringo and Peltier, 1996). This modality of leaf water potential has been proven more useful than predawn leaf water potential for estimating the vine water status of Galician grapevine cultivars (MirásAvalos et al., 2014).

Stomatal conductance was measured fortnightly on one healthy, mature and fully-expanded leaf per plant and two plants per replicate (eight plants per treatment) using a leaf porometer (Model SC1 Decagon Devices, WA, USA). The leaves were exposed to sunlight. Measurements were always performed between 11:30 $\mathrm{h}$ and 12:30 h.

\section{Chlorophyll a measurements}

Chlorophyll $a$ (Chl $a$ ) fluorescence parameters were measured in situ with a pulse-amplitude-modulated fluorometer (FMS 2, Hansatech Instruments, Norfolk, UK) as described by Moutinho-Pereira et al. (2012), on the same leaves where stomatal conductance was measured. Leaves were dark-adapted for at least 30 minutes using dark-adapting leaf-clips. Several photosystem II (PSII) parameters were obtained (Maxwell and Johnson, 2000): the maximum quantum efficiency of PSII $\left(F_{v} / F_{m}\right)$, the photochemical efficiency of PSII (ФPSII), the electron transport rate (ETR), photochemical quenching $\left(\mathrm{q}_{\mathrm{P}}\right)$, non-photochemical quenching (NPQ) and the steady-state fluorescence yield $\left(F_{s}\right)$.

Chl $a$ fluorescence measurements were always performed between 11:30 $\mathrm{h}$ and 13:30 h at maturation (beginning or mid-August). In 2013, these determinations were not taken due to equipment malfunctioning.

\section{Chlorophyll content index (CCI)}

Chlorophyll concentration index (CCI) was also estimated non-destructively using a CCM-200 portable chlorophyll meter (Opti-Sciences, Tyngsboro, MA, USA), which calculates a unitless CCI value from the ratio of optical absorbance at 655 $\mathrm{nm}$ to that at $940 \mathrm{~nm}$. These measurements were performed on three leaves per plant and twelve plants per treatment. Major veins and areas of obvious visual damage or disease were avoided. CCI values have been reported to be correlated with total foliar extractable chlorophyll (Steele et al., 2008).

\section{Leaf element concentration measurement}

Leaves from two replications of the three different treatments were collected at veraison, ground and analyzed each season for element concentration.
$\mathrm{N}, \mathrm{P}$ and $\mathrm{B}$ were determined by molecular absorption spectrophotometry, after digestion with $\mathrm{H}_{2} \mathrm{SO}_{4}$ and $\mathrm{H}_{2} \mathrm{O}_{2}$ (Mills and Benton Jones 1996). Plant concentration of other elements was determined by atomic absorption spectrophotometry $(\mathrm{Ca}, \mathrm{Mg}$ and $\mathrm{Fe}$ ) or by flame emission photometry (K), after digestion with $\mathrm{HNO}_{3}$ and $\mathrm{HClO}_{4}$ (Mills and Benton Jones, 1996). Element concentration was expressed on a dry mass basis.

\section{Foliar metabolic assays and oxidative stress indicators}

These determinations were performed on leaf discs from eight leaves randomly collected per treatment at the ripeness stage in 2012 and 2013. Leaves were fully expanded, of comparable physiological ages and with no visual signs of damage. They were frozen in liquid nitrogen and stored at $-80{ }^{\circ} \mathrm{C}$ prior to analysis, which were perfomed as described by Dinis et al. (2014).

Briefly, leaf sections were ground in $80 \%$ acetone for chlorophyll and carotenoid determination. Total chlorophyll $\left(\mathrm{Chl}_{\mathrm{tot}}\right)$ concentration (Sesták et al., 1971) and total carotenoids (Car) concentration (Lichtenthaler, 1987) were determined. Total soluble sugars (SS) were extracted by heating leaf discs in $80 \%$ ethanol and obtained according to Irigoyen et al. (1992). After the extraction of the soluble fractions, the solid fraction was used for starch analysis. Starch was extracted with $30 \%$ perchloric acid (Osaki et al. 1991). The concentration of total phenols (TP) in leaf extracts was determined on the same extract used for pigment analysis, according to the Folin-Ciocalteu's procedure (Singleton and Rossi, 1965). The amount of total soluble proteins (SP) was quantified using the method of Bradford (1976). Bovine serum albumin was used as a standard.

The lipid peroxidation products (total thiobarbituric acid reactive substances, TBARS) in grape leaves were estimated using the procedures described by Heath and Packer (1968) with the adaptations reported by Dinis et al. (2014).

All reagents and chemicals used were of the highest commercially-available grade of purity.

At harvest (September $7^{\text {th }}, 16^{\text {th }}$ and $3^{\text {rd }}$ for 2012, 2013 and 2014, respectively), the number of clusters per vine was counted and yield per vine was determined on-site after manual harvesting and weighing the production. Pruning weight (PW) was determined at winter in five vines per replicate.

\section{Statistical analysis}

Analysis of variance was performed using the "aov" procedure of the R statistical software (R Core Team, 
2015). Means were separated using the Tukey's Honest Significant Difference test. Differences were considered significant when $\mathrm{p}<0.05$.

\section{RESULTS AND DISCUSSION}

\section{Climate and plant water relations}

Higher rainfall amount was recorded during the 2012 growing season (from $1^{\text {st }}$ April to harvest), $252 \mathrm{~mm}$ against 140 and $152 \mathrm{~mm}$ observed in 2013 and 2014, respectively. This rainfall was mainly concentrated in the months of April and May, with occasional events in the rest of the months (Figure 1), which were more frequent in 2012 and 2014. Mean air temperature for the growing season was $16.6,17.0$ and $17.3{ }^{\circ} \mathrm{C}$ for 2012, 2013 and 2014, respectively. $\mathrm{ET}_{\mathrm{o}}$ over the growing season was similar for 2012 and 2013, with 628 and $632 \mathrm{~mm}$, respectively, while in 2014 the $\mathrm{ET}_{0}$ was $689 \mathrm{~mm}$.
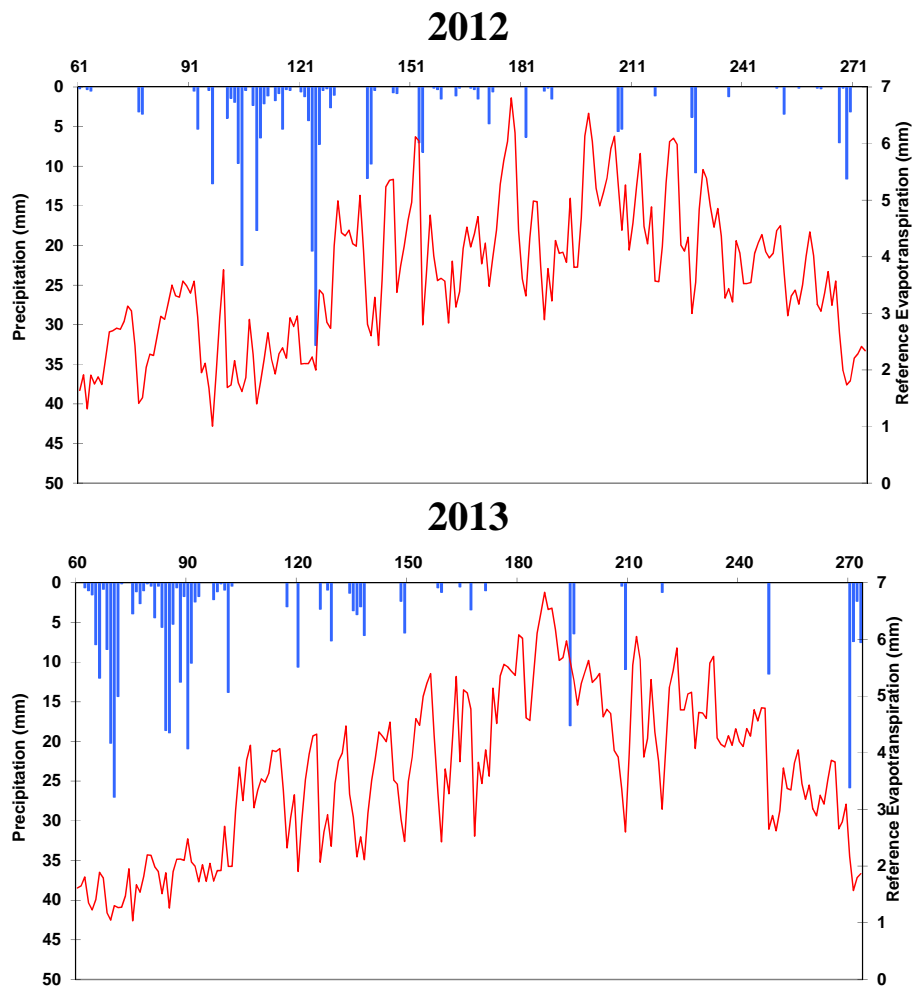

2014

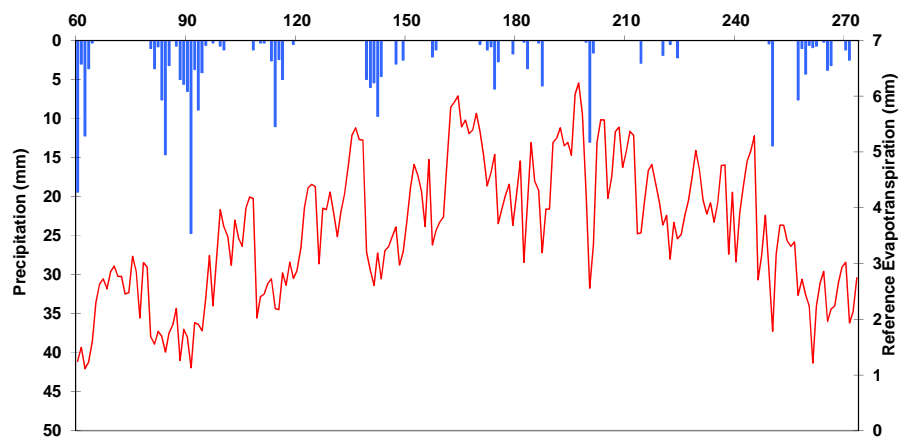

Figure 1. Total rainfall (bars) and daily reference evapotranspiration (lines) at the experimental site during the seasons of 2012,2013 and 2014. Data in the $\mathrm{X}$-axis refer to the day of the year.

Precipitação (barras) e evapotranspiração de referência (linhas) diárias na parcela experimental durante as campanhas 2012, 2013 e 2014. Os dados no eixo $X$ referem-se aos dias do ano. 
Midday leaf water potential showed a progressive decline over the growing season for all treatments (Figure 2). Significantly lower values were measured in R plants, especially in 2012 and 2013 (Figure 2). In contrast, in 2014, leaf water potential was very similar among treatments except for a single date close to harvest, which might have been caused by a higher maximum temperature and a lower relative humidity when compared to the following measurement date. Moreover, stem water potential measurements (Cancela et al., 2016) confirmed that vine water status was similar between treatments during the 2014 growing season. The lowest midday leaf water potential values were observed in $\mathrm{R}$ plants in 2013, when they attained $-1.5 \mathrm{MPa}$; however, in
2014 the lowest value was $-1 \mathrm{MPa}$. In general, the trend observed in the three growing seasons was that $\mathrm{R}$ plants showed the most negative leaf water potential values and SDI plants the least negative ones. DI plants presented intermediate values for this parameter when compared with those of R and SDI plants; this might have been due to the fact that the SDI treatment had not direct losses through evaporation since the irrigation pipes were buried, therefore, more water is available to the vines. This different distribution of the irrigation pipes provided a slightly different pattern of soil water content between the two irrigated treatments (Cancela et al., 2016), which may explain the differences in leaf water potential observed here.

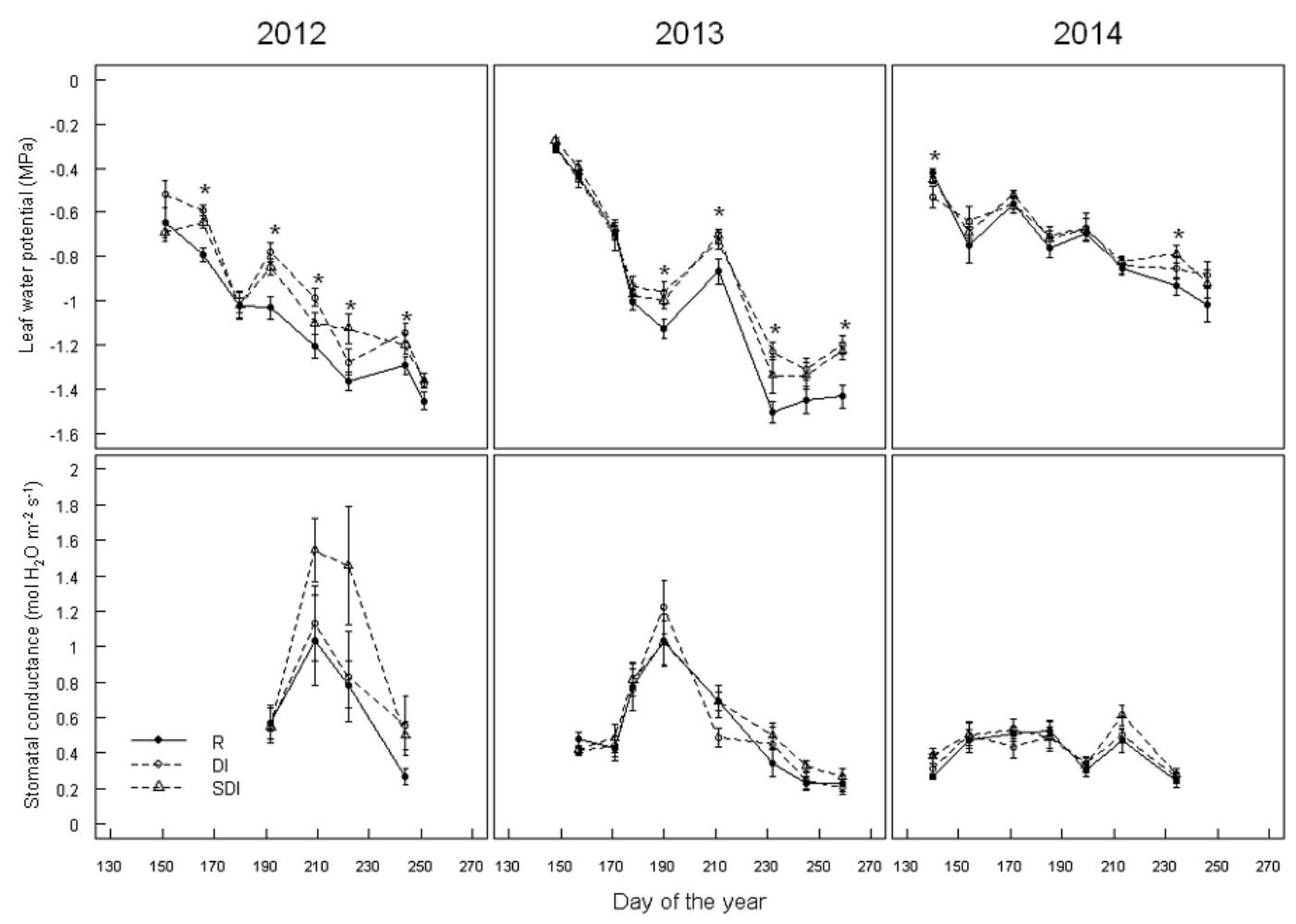

Figure 2. Seasonal evolution of midday leaf water potential and stomatal conductance for the three treatments $(\mathrm{R}=$ rain-fed; $\mathrm{DI}=$ surface drip irrigation; SDI = subsurface drip irrigation) studied during 2012, 2013 and 2014 growing seasons. Each point represents the average of 12 and 8 measurements for leaf water potential and stomatal conductance, respectively. Bars indicate the standard error of the mean. Asterisks indicate significant differences among treatments $(\mathrm{p}<0.05)$.

Evolução temporal do potencial hídrico foliar ao meio dia e da conductância estomática para os três tratamentos $(R=$ sequeiro; $D I=$ rega por gotejo superficial; $S D I$ = rega por gotejo subsuperficial). Cada ponto representa a média de 12 e 8 medições para o potencial hídrico foliar e a conductância estomática, respectivamente. As barras indicam os erros padrão. Os asteriscos indicam diferenças significativas entre os tratamentos $(p<0,05)$.

Stomatal conductance values were high for the three treatments, especially in 2012, and presented a great variability. Therefore, non-significant differences were detected among treatments (Figure 2).
Moreover, R plants tended to show slightly lower values for this parameter.

The present study was carried out in a region with sub-humid climate but where moderate to strong 
water stress can occur. In this region, grapevine irrigation is not a common practice but, recently, as a consequence of dry weather, vinegrowers began to install conventional drip irrigation systems aiming to stabilize yield and wine quality from year to year (Cancela et al., 2016). In the three years of our experiment, the annual rainfall was greater than 540 $\mathrm{mm}$; however, rainfall over the growing cycle $\left(1^{\text {st }}\right.$ April to harvest) was lesser than $200 \mathrm{~mm}$ (except for 2012). Consequently, non-irrigated vines were subjected only to a mild water stress and the effect of irrigation was not of the magnitude expected in dry years. This resulted in small differences on midday leaf water potential among treatments.

The small differences on water status among treatments were in agreement with the absence of a decrease in stomatal conductance in the non-irrigated vines when compared to that of the irrigated treatments. Stomatal closure is the first sign of plant defense in maintaining its water status (Suzy et al., 2011) and it was not observed in the current study. This suggests that vine physiology and functioning were not restricted under our given conditions and that irrigation did not improve these processes.

In addition, the stomatal conductance values observed at midday in the current study were greater than those reported by other authors (de Souza et al., 2003; Medrano et al., 2003), who worked under Mediterranean climate conditions. The fact that the measurement interval of the equipment used is rather narrow, measurements greater than $0.7 \mathrm{~mol} \mathrm{H}_{2} \mathrm{O} / \mathrm{m}^{2} / \mathrm{s}$ should be taken with caution. However, comparisons between treatments are allowed because all the measurements were performed with the same equipment and conditions. In addition, the stomatal conductance values measured in the current study are of the same order of magnitude as those reported by Williams and Trout (2005) for 'Thompson Seedless' and those measured in the morning by Dinis et al. (2014) in a Mediterranean climate. This suggests that stomatal conductance peaks were not displaced towards the early hours of the day in 'Godello' vines of Valdeorras DO. In fact, midday leaf water potential and stomatal conductance values measured in the current work are over the optima $(-1.25$ to $-1.4 \mathrm{MPa}$ and 0.12 to $0.15 \mathrm{~mol} \mathrm{H}_{2} \mathrm{O} / \mathrm{m}^{2} / \mathrm{s}$, respectively) suggested by Romero et al. (2010) for 'Monastrell' cultivar under the semi-arid conditions of south east Spain. Being above these optima indicated that vines did not suffer from water stress, explaining the absence of differences among treatments in the current study.

\section{Chlorophyll fluorescence attributes}

Chlorophyll a fluorescence attributes were very similar among treatments (Table 1$) . F_{v} / F_{m}$ was almost equal between $\mathrm{R}$ plants and those subjected to irrigation in both years; moreover, this parameter was close to or higher than 0.8. ETR and NPQ did not present significant differences between treatments due to a high variability of measurements. In contrast, the effective quantum yield efficiency of photosystem II (ФPSII) was higher in DI plants in 2014 (Table I). The same was observed for $\mathrm{q}_{\mathrm{p}}$ in 2014. In addition, steady-state fluorescence $\left(F_{s}\right)$ was greater in R plants in 2012.

Table I

Maximum $\left(F_{\sqrt{ }} / F_{m}\right)$ and effective (ФPSII) quantum efficiency of photosystem II, apparent electron transport rate (ETR), photochemical (q $)$ and non-photochemical (NPQ) fluorescence quenching and fluorescence in steady-state $\left(F_{s}\right)$ in 'Godello' grapevine attached leaves as a function of irrigation system $(\mathrm{R}=$ rain-fed; $\mathrm{DI}$ = surface drip irrigation; SDI = subsurface drip irrigation) determined during the ripening period (9 August 2012 and 1 August 2014).

Eficiência máxima $\left(F_{v} / F_{m}\right)$ e efetiva ( $\left.P P S I I\right)$ do fotosistema II, taxa aparente de transporte eletrónico (ETR), quenching fotoquímico ( $\left.q_{P}\right)$ e nãofotoquímico (NPQ), e fluorescencia em estado estacionário $\left(F_{s}\right)$ em folhas da variedade 'Godello' em função do tratamento de rega $(R=$ sequeiro; DI = rega por gotejo superficial; SDI = rega por gotejo subsuperficial) durante o período de maturação (9 Agosto 2012 e 1 Agosto 2014).

\begin{tabular}{|l|c|c|c|c|c|c|}
\hline Treatment & $F_{v} / F_{m}$ & $\Phi_{P S I}$ & ETR & qP & NPQ & $F_{s}$ \\
\hline \multicolumn{7}{|c|}{9 August 2012} \\
\hline R & $0.78 \mathrm{a}$ & $0.42 \mathrm{a}$ & $62.29 \mathrm{a}$ & $0.46 \mathrm{a}$ & $0.81 \mathrm{a}$ & $346.70 \mathrm{~b}$ \\
\hline DI & $0.79 \mathrm{a}$ & $0.57 \mathrm{a}$ & $51.15 \mathrm{a}$ & $0.63 \mathrm{a}$ & $0.84 \mathrm{a}$ & $270.35 \mathrm{ab}$ \\
\hline SDI & $0.79 \mathrm{a}$ & $0.55 \mathrm{a}$ & $68.35 \mathrm{a}$ & $0.61 \mathrm{a}$ & $0.86 \mathrm{a}$ & $246.45 \mathrm{a}$ \\
\hline \multicolumn{7}{|c|}{1 August 2014} \\
\hline R & $0.87 \mathrm{a}$ & $0.36 \mathrm{a}$ & $63.95 \mathrm{a}$ & $0.41 \mathrm{ab}$ & $0.72 \mathrm{a}$ & $286.23 \mathrm{a}$ \\
\hline DI & $0.88 \mathrm{a}$ & $0.48 \mathrm{a}$ & $71.29 \mathrm{a}$ & $0.52 \mathrm{~b}$ & $0.70 \mathrm{a}$ & $265.00 \mathrm{a}$ \\
\hline SDI & $0.87 \mathrm{a}$ & $0.33 \mathrm{a}$ & $77.82 \mathrm{a}$ & $0.33 \mathrm{a}$ & $0.75 \mathrm{a}$ & $306.60 \mathrm{a}$ \\
\hline
\end{tabular}


At the photosynthetic level, 'Godello' vines did not present symptoms of photoinhibition since $F_{v} / F_{m}$ was approximately 0.8 , the value of healthy terrestrial plants (Cavender-Bares and Bazzaz, 2004). Moreover, this parameter was unaffected by the irrigation treatment, suggesting that it is not the ideal indicator to evaluate water status under field conditions. Furthermore, the fluorescence measurements done in leaves previously exposed to sunlight did not reflect a clear trend in the data; ФPSII and $\mathrm{q}_{\mathrm{p}}$ increased in DI plants in 2014 but no effect was observed in NPQ, then a down-regulation of electron transport caused by a reduction of the fraction of open action centres cannot be concluded. Finally, steady-state chlorophyll fluorescence $\left(F_{s}\right)$ did not reflect drought intensity and was even higher for
R plants in 2012; therefore, it might not be an useful parameter for remote sensing of vine water status, as suggested by other authors (Medrano et al., 2003).

\section{Chlorophyll content index}

Values of CCI did not significantly differ among treatments (Figure 3) due to the high variability of these measurements. However, in 2013, lower CCI values were systematically observed for R plants, in agreement with the leaf photosynthetic pigment composition results observed for that season. This suggests that CCI might be a useful tool for agronomic and environmental studies due to its quickness, user-friendliness and being no-destructive (Steele et al., 2008). Nevertheless, this trend was not maintained in 2014.

\section{3}

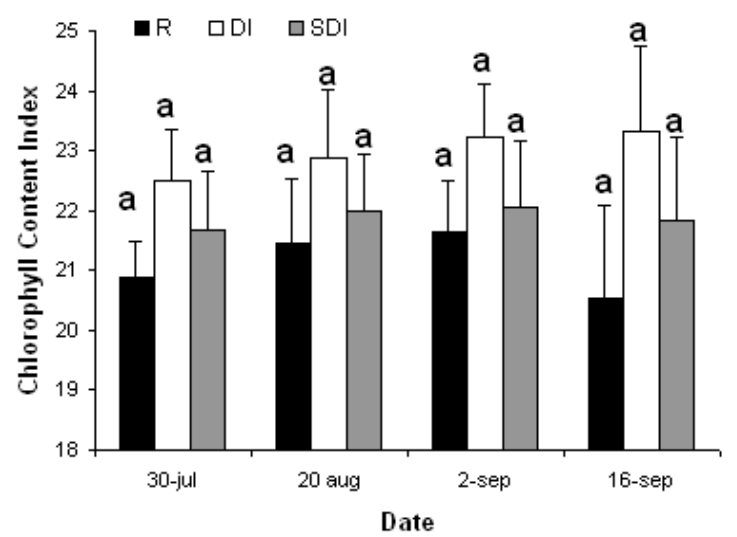

2014

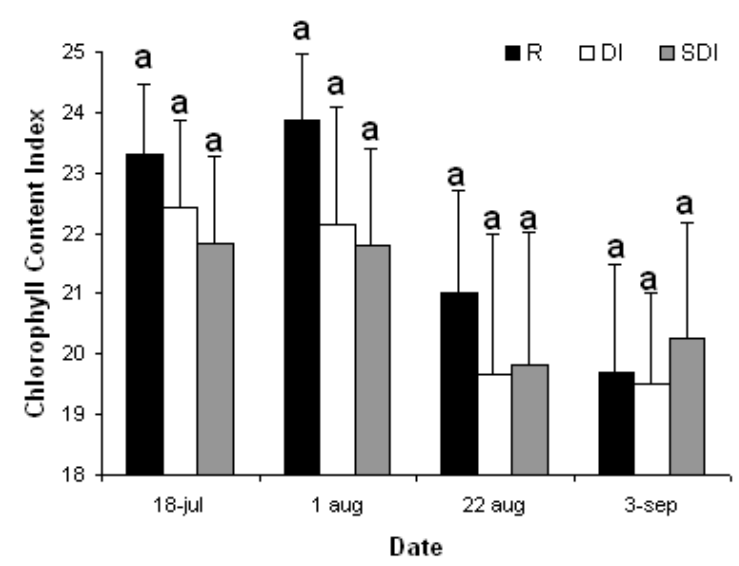

Figure 3. CCI values of 'Godello' grapevine attached leaves subjected to different treatments $(\mathrm{R}=$ rain-fed; $\mathrm{DI}=$ surface drip irrigation; SDI = subsurface drip irrigation) during the 2013 and 2014 growing seasons. Bars indicate the standard error of the mean. The same letters on the top of the bars for a given date indicate the absence of significant differences among treatments $(\mathrm{p}<0.05)$.

Valores de CCI para folhas da variedade 'Godello' submetidas aos três tratamentos estudados $(R=$ sequeiro; DI = rega por gotejo superficial; $S D I=$ rega por gotejo subsuperficial) durante os anos 2013 e 2014. As barras indicam os erros padrão. As mesmas letras no topo das barras para uma determinada data indicam a ausência de diferenças significativas entre os tratamentos $(p<0,05)$.

\section{Foliar mineral content}

In general, no significant differences were found among treatments except for certain years (Table II). $\mathrm{R}$ plants presented higher contents of $\mathrm{N}$ than those irrigated in 2012, but this trend was not observed in the rest of the studied seasons. In contrast, SDI plants showed lower concentrations of K, Zn and B in 2013. In 2014, irrigated plants presented lesser concentrations of $\mathrm{P}$ and $\mathrm{Fe}$ than $\mathrm{R}$ plants. Interestingly, the two most important elements for determining water stress in plants ( $\mathrm{Ca}$ and $\mathrm{Mg}$ ) were unaffected by the irrigation treatment. 
Table II

Leaf foliar mineral concentration of ‘Godello' cultivar under the three treatments $(\mathrm{R}=$ rain-fed; DI = surface drip irrigation; SDI = subsurface drip irrigation) studied in 2012, 2013 and 2014 in leaves collected in July (veraison).

Concentração foliar de minerais na variedade 'Godello' nos três tratamentos estudados $(R=$ sequeiro; DI = rega por gotejo superficial; SDI = rega por gotejo subsuperficial) em 2012, 2013 e 2014 em folhas colhidas em julho (pintor).

\begin{tabular}{|c|c|c|c|c|c|c|c|c|}
\hline \multirow{2}{*}{ Season } & \multirow{2}{*}{ Treatment } & $\mathrm{N}$ & $P$ & $\mathrm{~K}$ & $\mathrm{Ca}$ & $\mathrm{Mg}$ & $\mathrm{Fe}$ & B \\
\hline & & \multicolumn{5}{|c|}{$\mathrm{G} \mathrm{kg}^{-1}$} & \multicolumn{2}{|c|}{$\mathrm{mg} \mathrm{kg}^{-1}$} \\
\hline \multirow[t]{3}{*}{2012} & $\mathrm{R}$ & $24.8 \mathrm{~b}$ & $1.4 \mathrm{a}$ & $18.8 \mathrm{a}$ & $12.5 \mathrm{a}$ & $1.3 \mathrm{a}$ & $86.9 \mathrm{a}$ & $26.3 \mathrm{a}$ \\
\hline & DI & $26.0 \mathrm{~b}$ & $1.7 \mathrm{a}$ & $18.4 \mathrm{a}$ & $13.2 \mathrm{a}$ & $1.3 \mathrm{a}$ & $90.0 \mathrm{a}$ & $31.0 \mathrm{a}$ \\
\hline & SDI & $22.3 \mathrm{a}$ & $1.6 \mathrm{a}$ & $18.9 \mathrm{a}$ & $12.7 \mathrm{a}$ & $1.4 \mathrm{a}$ & $112.2 \mathrm{~b}$ & $28.5 \mathrm{a}$ \\
\hline \multirow[t]{3}{*}{2013} & $\mathrm{R}$ & $22.8 \mathrm{a}$ & $1.4 \mathrm{a}$ & $19.4 \mathrm{~b}$ & $11.0 \mathrm{a}$ & $1.8 \mathrm{a}$ & $71.0 \mathrm{a}$ & $19.5 \mathrm{~b}$ \\
\hline & DI & $24.4 \mathrm{a}$ & $1.6 \mathrm{a}$ & $19.8 \mathrm{~b}$ & $11.8 \mathrm{a}$ & $1.6 \mathrm{a}$ & $83.0 \mathrm{a}$ & $21.5 \mathrm{~b}$ \\
\hline & SDI & $24.6 \mathrm{a}$ & $1.7 \mathrm{a}$ & $16.7 \mathrm{a}$ & $12.1 \mathrm{a}$ & $1.5 \mathrm{a}$ & $87.5 \mathrm{a}$ & $16.5 \mathrm{a}$ \\
\hline \multirow[t]{3}{*}{2014} & $\mathrm{R}$ & $39.1 \mathrm{a}$ & $2.4 \mathrm{~b}$ & $10.8 \mathrm{a}$ & $8.4 \mathrm{a}$ & $1.7 \mathrm{a}$ & $64.7 \mathrm{~b}$ & $25.7 \mathrm{a}$ \\
\hline & DI & $39.3 \mathrm{a}$ & $2.2 \mathrm{a}$ & $10.3 \mathrm{a}$ & $9.2 \mathrm{a}$ & $1.7 \mathrm{a}$ & $61.1 \mathrm{a}$ & $29.2 \mathrm{a}$ \\
\hline & SDI & $38.6 \mathrm{a}$ & $2.2 \mathrm{a}$ & $8.4 \mathrm{a}$ & $10.5 \mathrm{a}$ & $1.8 \mathrm{a}$ & $61.1 \mathrm{a}$ & $29.2 \mathrm{a}$ \\
\hline
\end{tabular}

\section{Leaf metabolites}

No signs of treatment effects on leaf photosynthetic pigments were observed in 2012 (Table III); which is in agreement with the fluorescence readings. The only exception was SS, which were observed in higher concentrations in $\mathrm{R}$ plants. In contrast, lower values of $\mathrm{Chl}_{\text {tot }}$ and $\mathrm{Car}_{\text {tot }}$ were detected for leaves of $\mathrm{R}$ plants in 2013, indicating the higher water stress suffered by these vines, as observed under drought conditions by Dinis et al. (2014). Lower values of SP were observed for DI plants and higher concentrations of TBARS in $\mathrm{R}$ plants were detected in 2013 (Table III). Interestingly, TBARS concentration could be considered as a biochemical marker for reactive oxygen species mediated injury, hence in 2013 the higher concentration of TBARS in $\mathrm{R}$ plants confirmed a greater oxidative damage of cell membranes by lipid peroxidation (Beis and Patakas, 2012).

One of the most important responses of plants to drought is an overproduction of different types of compatible solutes, namely total free amino acids, proteins and soluble sugars (Irigoyen et al., 1992). Data from 2013 indicated higher contents of SS, SP and TBARS in leaves from R plants, similarly to the trends previously reported (Beis and Patakas, 2012; Dinis et al., 2014).

\section{Yield parameters and pruning weight}

No significant differences among treatments were detected for yield components and pruning weight (Table IV). The only exception was the number of clusters per vine in 2013, which was higher for SDI vines and might be due to greater bud fertility in the vines from the SDI treatment. However, a trend to higher yields and pruning weights was observed for DI and SDI vines when compared to those under R. In a previous study in this vineyard, Cancela et al. (2016) observed no significant differences in berry composition (probable alcohol, $\mathrm{pH}$, titratable acidity, malic and tartaric acid concentrations) among treatments.

These results can be explained by the mild water stress observed in $\mathrm{R}$ plants and by the fact that the rainfall amount registered at the experimental plot was rather high, especially in 2014. Similar observations have been reported by other authors (dos Santos et al., 2003). In addition, in 2012 and 2013, when less rainfall was registered over the year, slight yield increases in the irrigated treatments were observed, which may indicate that this trend would be maintained in dry years. 
Table III

Leaf concentration of photosynthetic pigments (total chlorophyll, Chl $\mathrm{tot}_{\text {; }}$ total carotenoids, $\mathrm{Car}_{\text {tot }}$; total chlorophyll/total carotenoids ratio, Chl/Car), carbohydrates (soluble sugars, SS; starch, St), soluble proteins (SP), total phenols (TP) and total thiobarbituric acid reactive substances (TBARS)

in leaves collected in August (ripeness) of the 'Godello' cultivar under the three treatments ( $\mathrm{R}=$ rain-fed; DI = surface drip irrigation; SDI = subsurface drip irrigation) studied in 2012 and 2013

Concentração de pigmentos fotossintéticos (clorofila total, Chl tot $_{\text {; }}$ carotenoides totais, Car ${ }_{\text {tot; }}$ razão clorofila total/carotenoides totais, Chl/Car), carbohidratos (açúcares solúveis, SS; amido, St), proteínas solúveis (SP), fenóis totais (TP) e substâncias reactivas ao ácido tiobarbitúrico (TBARS) em folhas colhidas em Agosto (maturação) da variedade 'Godello' nos três tratamentos estudados $(R=$ sequeiro; DI = rega por gotejo superficial; SDI = rega por gotejo subsuperficial) em 2012 e 2013.

\begin{tabular}{|c|c|c|c|c|}
\hline Season & Variable & $\mathrm{R}$ & DI & SDI \\
\hline \multirow[t]{8}{*}{2012} & $\mathrm{Chl}_{\text {tot }}\left(\mathrm{mg} \mathrm{g}^{-1}\right)$ & $6.6 \mathrm{a}$ & $7.0 \mathrm{a}$ & $7.3 \mathrm{a}$ \\
\hline & $\operatorname{Car}_{\text {tot }}\left(\mathrm{mg} \mathrm{g}^{-1}\right)$ & $1.0 \mathrm{a}$ & $1.2 \mathrm{a}$ & $1.2 \mathrm{a}$ \\
\hline & $\mathrm{Chl} / \mathrm{Car}$ & $6.4 \mathrm{a}$ & $5.9 \mathrm{a}$ & $6.1 \mathrm{a}$ \\
\hline & $\mathrm{SS}\left(\mathrm{mg} \mathrm{g}^{-1}\right)$ & $171.7 \mathrm{~b}$ & $154.6 \mathrm{a}$ & $141.7 \mathrm{a}$ \\
\hline & St $\left(\mathrm{mg} \mathrm{g}^{-1}\right)$ & $127.2 \mathrm{a}$ & $145.0 \mathrm{a}$ & $129.3 \mathrm{a}$ \\
\hline & $\mathrm{SP}\left(\mathrm{mg} \mathrm{g}^{-1}\right)$ & $60.2 \mathrm{a}$ & $50.3 \mathrm{a}$ & $57.0 \mathrm{a}$ \\
\hline & $\mathrm{TP}\left(\mathrm{mg} \mathrm{g}^{-1}\right)$ & $101.8 \mathrm{a}$ & $97.4 a$ & $102.1 \mathrm{a}$ \\
\hline & TBARS $\left(\mu \mathrm{mol} \mathrm{g}{ }^{-1}\right)$ & $16.6 \mathrm{a}$ & $14.9 \mathrm{a}$ & $15.3 \mathrm{a}$ \\
\hline \multirow[t]{8}{*}{2013} & $\mathrm{Chl}_{\text {tot }}\left(\mathrm{mg} \mathrm{g}^{-1}\right)$ & $1.6 \mathrm{a}$ & $2.3 \mathrm{~b}$ & $2.1 \mathrm{~b}$ \\
\hline & $\mathrm{Car}_{\text {tot }}\left(\mathrm{mg} \mathrm{g}^{-1}\right)$ & $0.4 \mathrm{a}$ & $0.5 \mathrm{~b}$ & $0.5 \mathrm{~b}$ \\
\hline & Chl/Car & $4.2 \mathrm{a}$ & $4.6 \mathrm{~b}$ & $4.5 \mathrm{~b}$ \\
\hline & $\mathrm{SS}\left(\mathrm{mg} \mathrm{g}^{-1}\right)$ & $55.7 \mathrm{~b}$ & $41.5 \mathrm{a}$ & $39.1 \mathrm{a}$ \\
\hline & St $\left(\mathrm{mg} \mathrm{g}^{-1}\right)$ & $31.0 \mathrm{a}$ & 29.6 a & $29.1 \mathrm{a}$ \\
\hline & $\mathrm{SP}\left(\mathrm{mg} \mathrm{g}^{-1}\right)$ & $13.9 \mathrm{ab}$ & $10.2 \mathrm{a}$ & $17.1 \mathrm{~b}$ \\
\hline & $\mathrm{TP}\left(\mathrm{mg} \mathrm{g}^{-1}\right)$ & 45.9 a & 44.7 a & 44.3 a \\
\hline & TBARS $\left(\mu \mathrm{mol} \mathrm{g}{ }^{-1}\right)$ & $3.9 \mathrm{~b}$ & $2.9 \mathrm{a}$ & $3.3 \mathrm{ab}$ \\
\hline
\end{tabular}

Table IV

Yield, number of clusters per plant and pruning weight of 'Godello' grapevines under the three treatments studied (R = rain-fed; DI = surface drip irrigation; SDI = subsurface drip irrigation) determined in the 2012, 2013 and 2014 experiments.

Rendimento, número de cachos e peso da lenha de poda por planta na variedade 'Godello' nos três tratamentos estudados $(R=$ sequeiro; $D I=$ rega por gotejo superficial; SDI = rega por gotejo subsuperficial) nos anos 2012, 2013 e 2014.

\begin{tabular}{|c|c|c|c|c|}
\hline Season & Variables & $\mathrm{R}$ & DI & SDI \\
\hline \multirow[t]{3}{*}{2012} & Yield (kg vine ${ }^{-1}$ ) & $2.89 \mathrm{a}$ & $2.94 \mathrm{a}$ & $3.50 \mathrm{a}$ \\
\hline & Clusters (number vine ${ }^{-1}$ ) & $22.18 \mathrm{a}$ & $19.44 \mathrm{a}$ & $21.57 \mathrm{a}$ \\
\hline & Pruning weight (kg vine ${ }^{-1}$ ) & $0.69 \mathrm{a}$ & $0.86 \mathrm{a}$ & $0.67 \mathrm{a}$ \\
\hline \multirow[t]{3}{*}{2013} & Yield (kg vine ${ }^{-1}$ ) & $3.20 \mathrm{a}$ & 3.69 a & $4.18 \mathrm{a}$ \\
\hline & Clusters (number vine ${ }^{-1}$ ) & $21.32 \mathrm{a}$ & $20.79 \mathrm{a}$ & $26.68 \mathrm{~b}$ \\
\hline & Pruning weight (kg vine ${ }^{-1}$ ) & $0.68 \mathrm{a}$ & $0.77 \mathrm{a}$ & $0.73 \mathrm{a}$ \\
\hline \multirow[t]{3}{*}{2014} & Yield (kg vine ${ }^{-1}$ ) & $2.87 \mathrm{a}$ & $2.72 \mathrm{a}$ & $2.42 \mathrm{a}$ \\
\hline & Clusters (number vine ${ }^{-1}$ ) & $22.86 \mathrm{a}$ & $21.36 \mathrm{a}$ & $19.32 \mathrm{a}$ \\
\hline & Pruning weight (kg vine ${ }^{-1}$ ) & $0.90 \mathrm{a}$ & $1.11 \mathrm{a}$ & $0.95 \mathrm{a}$ \\
\hline
\end{tabular}

Different letters in the row indicate significant differences between treatments at $\mathrm{p}<0.05$. 


\section{CONCLUSIONS}

Under the conditions of the current study (mild water stress and low evapotranspiration demand), irrigation treatments did not exert a clear influence on the considered physiological, biochemical and agronomical attributes. Vine water status was improved by irrigation; however, this did not induce a greater stomatal conductance or a higher yield in irrigated vines. In addition, the photosynthetic apparatus of 'Godello' vines was mainly unaffected by the irrigation treatments. Nevertheless, in certain seasons, oxidative stress indicators were significantly greater in non-irrigated vines, as well as lower efficiencies in photosystem II activity. The absence of significant differences between irrigate and rainfed vines may not encourage growers to establish drip irrigation systems on their vineyards. However,

\section{REFERENCES}

Allen R.G., Pereira L.S., Raes D., Smith M., 1998 Crop evapotranspiration: guidelines for computing crop water requirements, Irrigation and Drainage Paper 56. 300 p. United Nations FAO, Rome.

Battilani A., Mannini P., 2000. Grapevine (Vitis vinifera) yield and quality response to irrigation. Acta Hortic., 537, 895-902.

Beis A., Patakas A., 2012. Relative contribution of photoprotection and antioxidative mechanisms to differential drought adaptation ability in grapevines. Environ. Exp. Bot., 78, 173-183.

Bradford M.M., 1976. A rapid and sensitive method for the quantification of microgram quantities of protein utilizing the principle of protein-dye binding. Anal. Biochem., 72, 248-254.

Cancela, J.J. Fandiño M., Rey B.J., Dafonte J., González X.P., 2017. Discrimination of irrigation water management effects in pergola trellis system vineyards using a vegetation and soil index. Agric. Water Manage., 183, 70-77.

Cancela J.J., Fandiño M., Rey B.J., Martínez E.M., 2015. Automatic irrigation system based on dual crop coefficient, soil and plant water status for Vitis vinifera (cv Godello and cv Mencía). Agric. Water Manage., 151, 52-63.

Cancela J.J., Trigo-Córdoba, E., Martínez E.M., Rey B.J., BouzasCid Y., Fandiño M., Mirás-Avalos J.M., 2016. Effects of climate variability on irrigation scheduling in white varieties of Vitis vinifera (L.) of NW Spain. Agric. Water Manage., 170, 99-109.

Cavender-Bares J., Bazzaz F.A., 2004. From leaves to ecosystems: using chlorophyll fluorescence to assess photosynthesis and plant function in ecological studies. In: Chlorophyll a Fluorescence: a Signature of Photosynthesis. 737-755. Papageorgiou G.C., Govindjee G. (eds.), Springer, Amsterdam.

Chaves M.M., Pereira J.S., Maroco J.P., Rodrigues M.L., Ricardo C.P.P., Osório M.L., Carvalho I., Faria T., Pinheiro C., 2002. How plants cope with water stress in the field. Photosynthesis and growth. Ann. Bot., 89, 1-10.

Cruz R., Lago A., Rial M.E., Díaz-Fierros F., Salsón S., 2009. Evolución recente do clima de Galicia. Tendencias observadas en variables meteorolóxicas. In: Evidencias e Impactos do Cambio Climático en Galicia. 19-58. Consellería de Medio Ambiente e these results suggest that, in years with low spring rainfall, irrigation could provide a better plant functioning, which may be important to attain the objective of stabilizing yield from year to year.

\section{ACKNOWLEDGMENTS}

This research was supported by the Spanish Instituto Nacional de Investigación y Tecnología Agraria y Alimentaria (INIA), Project $\mathrm{n}^{\circ}$ RTA2011-00041-C0200, with $80 \%$ FEDER funds. J.M. Mirás-Avalos and E.M. Martínez thank Xunta de Galicia for funding their contracts through the "Isidro Parga Pondal" and "Isabel Barreto" Programmes. E. Trigo-Córdoba thanks INIA for their PhD scholarship (FPI-INIA). Thanks to NaanDanJain Iberica, SL for providing the irrigation pipes and emitters.

Desenvolvemento Sostible, Xunta de Galicia, Santiago de Compostela.

de Souza C.R., Maroco J.P., dos Santos T.P., Rodríguez M.L., Lopes C.M., Pereira J.S., Chaves M.M., 2003. Partial rootzone drying: regulation of stomatal aperture and carbon assimilation in field-grown grapevines (Vitis vinifera cv. Moscatel). Funct. Plant Biol., 30, 653-662.

Dinis L-T., Correia C.M., Ferreira H.F., Gonçalves B., Gonçalves I., Coutinho J.F., Ferreira M.I., Malheiro A.C., Moutinho-Pereira J., 2014. Physiological and biochemical responses of Semillon and Muscat Blanc à Petit Grains winegrapes grown under Mediterranean climate. Sci. Hortic., 175, 128-138.

dos Santos T.P., Lopes C.M., Rodrigues M.L., Souza C.R., Maroco J.P., Pereira J.S., Silva J.R., Chaves M.M., 2003. Partial root zone drying: effects on growth and fruit quality of field-grown grapevines Vitis vinifera L. Funct. Plant Biol., 30, 663-671.

Escalona J.M., Flexas J., Medrano H., 1999. Stomatal and nonstomatal limitations of photosynthesis under water stress in fieldgrown grapevines. Aus. J. Plant Physiol., 26, 421-433.

Fandiño M., Cancela J.J., Rey B.J., Martínez E.M., Rosa R.G., Pereira L.S., 2012. Using the dual-Kc approach to model evapotranspiration of Albariño vineyards (Vitis vinifera L. cv. Albariño) with consideration of active ground cover. Agric. Water Manag., 112, 75-87.

Fraga H., Malheiro A.C., Moutinho-Pereira J., Cardoso R.M., Soares P.M.M., Cancela J.J., Pinto J.G., Santos J.A., 2014. Integrated analysis of climate, soil, topography and vegetative growth in Iberian viticultural regions. PLOS One, 9, e108078.

Heath R.L., Packer L., 1968. Photoperoxidation in isolated chloroplasts. I. Kinetics and stoichiometry of fatty acid peroxidation. Arch. Biochem. Biophys., 125, 189-198.

Intrigliolo D.S., Castel J.R., 2010. Response of grapevine cultivar 'Tempranillo' to timing and amount of irrigation: water relations, vine growth, yield and berry and wine composition. Irrig. Sci., 28, 113-125.

Irigoyen J.J., Emerich D.W., Sánchez-Díaz M., 1992. Water stress induced changes in concentrations of proline and total soluble sugars in nodulated alfalfa (Medicago sativa) plants. Physiol. Plantarum, 84, 55-60. 
Lichtenthaler H.K., 1987. Chlorophylls and carotenoids: pigments of photosynthetic biomembranes. Method. Enzymol., 148, 350-382.

Maringo G., Peltier J.P., 1996. Analysis of the diurnal change in osmotic potential in leaves of Fraxinus excelsior L. J. Exp. Bot., 47, 763-769.

Maroco J.P., Rodrigues M.L., Lopes C., Chaves M.M., 2002. Limitations to leaf photosynthesis in field-grown grapevine under drought - metabolic and modelling approaches. Funct. Plant Biol., 29, 1-9.

Martínez, E.M., Rey, B.J., Fandiño, M., Cancela, J.J., 2013. Comparison of two techniques for measuring leaf water potential in Vitis vinifera var. Albariño. Ciência Tec. Vitiv. 28, 29-41.

Martínez, E.M., Rey, B.J., Fandiño, M., Cancela, J.J., 2016. Impact of water stress and nutrition on Vitis vinifera cv. 'Albariño': Soilplant water relationships, cumulative effects and productivity. Span. J. Agric. Res. 14(1), e1202, 15 pages

Maxwell K., Johnson G.N., 2000. Chlorophyll fluorescence - a practical guide. J. Exp. Bot., 51, 659-668.

Medrano H., Escalona J.M., Cifre J., Bota J., Flexas J., 2003. A ten-year study on the physiology of two Spanish grapevine cultivars under field conditions: effects of water availability from leaf photosynthesis to grape yield and quality. Funct. Plant Biol., 30, 607-619.

Mills H.A., Benton Jones J. Jr., 1996. Plant Analysis Handbook II. MicroMacro Publishing Inc., Athens, GA, USA.

Mirás-Avalos J.M., Trigo-Córdoba E., Bouzas-Cid Y., 2014. Does predawn water potential discern between irrigation treatments in Galician white grapevine cultivars? J. Int. Sci. Vigne Vin, 48, 123127.

Moutinho-Pereira J., Correia C.M., Gonçalves B., Bacelar E.A., Coutinho J.F., Ferreira H.F., Lousada J.L., Cortez M.I., 2012. Impacts of leafroll-associated viruses (GLRa-1 and -3) on the physiology of the Portuguese grapevine cultivar 'Touriga Nacional' growing under field conditions. Ann. Appl. Biol., 160, 237-249.
Osaki M., Shinano T., Tadano T., 1991. Redistribution of carbon and nitrogen compound from the shoot to the harvesting organs during maturation in field crops. Soil Sci. Plant Nutr., 37, 117-128.

R Core Team, 2015. R: A language and environment for statistical computing. R Foundation for Statistical Computing, Vienna, Austria. https://www.R-project.org/

Reynolds A.G., Lowrey W.D., Tomek L., Hakimi J., de Savigny C., 2007. Influence of irrigation on vine performance, fruit composition, and wine quality of Chardonnay in a cool, humid climate. Am. J. Enol. Vitic., 58, 217-228.

Romero P., Fernéndez-Fernández J.I., Martínez-Cutillas A., 2010. Physiological thresholds for efficient regulated deficit-irrigation management in winegrapes grown under semiarid conditions. Am. J. Enol. Vitic., 61, 300-312.

Sesták Z., Castky J., Jarvis P.G., 1971. Plant photosynthetic production. In: Manual of Methods. 818. Dr. W. Junk Publ., Haia.

Singleton V.L., Rossi J.A.J., 1965. Colorimetric of total phenolics with phosphomolybdic-phosphotungstic acid reagents. Am. J. Enol. Vitic., 16, 144-158.

Steele M.R., Gitelson A.A., Rundquist D.C., 2008. A comparison of two techniques for nondestructive measurement of chlorophyl content in grapevine leaves. Agron. J., 100, 779-782.

Suzy Y.R., Dennis H.G., Hutton R.J., Clarke S.J., 2011. Transpiration efficiency of the grapevine cv. Semillon is tied to VPD in warm climates. Ann. Appl. Biol., 158, 106-114.

Trigo-Córdoba E., Bouzas-Cid Y., Orriols-Fernández I., MirásAvalos J.M., 2015. Effects of deficit irrigation on the performance of grapevine (Vitis vinifera L.) cv. 'Godello' and 'Treixadura' in Ribeiro, NW Spain. Agric. Water Manage., 161, 20-30.

Williams L.E., Trout T.J., 2005. Relationships among vine- and soil-based measures of water status in a Thompson seedless vineyard in response to high-frequency drip irrigation. Am. J. Enol. Vitic., 56, 357-366. 